\title{
Mary Magdalene's Conversion in Renaissance Painting and Mediaeval Sacred Drama
}

\author{
Bram de Klerck
}

\section{Introduction}

Mary Magdalene's conversion to Christianity must have been a turning-point of paramount importance in her life. According to many a legendary source, the saint had been notorious for ostentatiously enjoying her youth, her physical beauty and her material wealth. At some point, however, she must have felt the urge to change her ways, to follow Jesus Christ and to dedicate herself to his teaching. The first manifestation of this is often considered to have been her humble and revering behaviour towards Christ when he stayed in the house of a Pharisee called Simon, as described in the Gospel according to St. Luke. A woman, in the Western tradition commonly identified with the Magdalene, entered the house, started weeping remorsefully over Christ's feet, and subsequently dried them with her own hair, kissed them and anointed them. If this nameless woman should indeed be identified with Mary Magdalene, this would imply that the latter's actual conversion had already occurred before the episode in the Pharisee's house. Surprisingly, this crucial moment in Mary's life has rarely been narrated in textual sources, nor has it very often been depicted in the visual arts

In the present contribution, I will explore the relationship between text and image, in relation to the portrayal of Mary Magdalene in the Late Middle Ages and the Renaissance in the Western World, and more specifically with regards to portrayals of her conversion. I will briefly introduce the complex legendary persona of the Magdalene as it emerges from biblical texts, as well as later legends. The reception of specific aspects of the Magdalene's legend in both high and low culture becomes clear through the presentation of her conversion in both popular theatre and more elitist manifestations in the visual arts. 


\section{Mary Magdalene: Written and Visual Evidence}

It is a well-known fact that in the Western tradition Mary Magdalene as a literary' character is the result of a fusion of several biblical and legendary figures. ${ }^{1}$ The evangelist Luke mentions a 'Mary, called Magdalene, out of whom went seven devils', as one of the women in Christ's company, who 'had been healed of evil spirits and infirmities' (Luke 8: 2). Mark says something similar: 'Now when Jesus was risen early the first day of the week, he appeared first to Mary Magdalene, out of whom he had cast seven devils' (Mark 16: 9). Other biblical examples which explicitly mention Mary Magdalene tell of her presence at Christ's crucifixion (Matthew 27: 56, Mark 15: 40, John 19: 25). The Evangelist John describes Mary's presence at Christ's burial, and her attempts to anoint the latter's body on Easter Morning, only to find the tomb empty (20: 1-18). Matthew, Mark and John, furthermore, describe her as the first witness to Christ's resurrection (Matthew 28: 9, Mark 16: 9, John 20:16-17).

Two other women described in the Bible have been associated with Mary Magdalene. One, mentioned above, is the anonymous penitent in the house of Simon the Pharisee (Luke 7: 36-39). The other is Mary, the sister of Martha who received Jesus in their house in the town of Bethany and prepared a meal for him (Luke 10: $38-42$ ). Their brother was Lazarus, a man who later would be raised from the dead by Christ (John 11:1-44). Probably referring to the woman in the house of the Pharisee, John says that 'it was that Mary which anointed the Lord with ointment, and wiped his feet with her hair' (11:1-2). This hypothetical identification would later became commonplace in the Roman Catholic tradition. In a homily on Luke's passage (Hom. xxxiii), the Pope and Church Father, Gregory the Great, explicitly presents these three women as being one and the same person, by stating that 'she whom Luke calls the sinful woman, whom John calls Mary [of Bethany], we believe to be the Mary from whom seven devils were ejected according to Mark.'2

After the events of Christ's death, burial and resurrection, Mary Magdalene vanishes from the canonical books. However, apocryphal sources dating from the first two or three centuries CE, such as the so-called 'Gospel of Philip' and the 'Gospel of Mary', stress other biographical aspects such as the reciprocal affection, or indeed physical attraction between Mary and Jesus. Recently, this fascinating information has met with a considerable response, especially in

1 The literature on Mary Magdalene is abundant. See, e.g.: Haskins (1993), Jansen (1999), Ricci, Marin (2006).

2 Homilia xxxiii: Gregory the Great (1999), p. 288-298, English quotation after Haskins 1993, p. 96. 
literary fiction, such as in Dan Brown's notorious Da Vinci Code (first published in 2003). But these apocryphal texts were unknown or at least not taken seriously by ecclesiastical authorities in the Late Middle Ages and Renaissance; they were rediscovered only in the late nineteenth and twentieth centuries and so do not concern us here. ${ }^{3}$

Hagiographical and theological literature, however, has contributed much to further shaping the Magdalene's legendary persona in the Late Middle Ages and the Early Modern period. The most detailed and best known of these sources is undoubtedly the compendium of saints' lives entitled Legenda aurea ('Golden Legend'), written by the Dominican friar Jacobus de Voragine in around $1260 .{ }^{4}$ It describes Mary as a member of a very affluent family, which owned pieces of land and even entire towns. One of these was Magdala on Lake Tiberias, hence Mary's surname 'of Magdala', or 'Magdalena'. Yet, the thirteenth-century author has surprisingly little to say about Mary's life before she became a follower of Jesus. Rather, he provides a lengthy description of the events of the latter phases of her life after Christ's death and resurrection, especially her stay in Southern France, after she had been expelled from Judea. According to Voragine, Mary converted the pagans living in Marseille, as well as their prefect, to Christianity, and subsequently spent the last years of her life in ascetic solitude in the wilderness of Provence. After she had died there, she was buried in St. Maximin's church in Aix-en-Provence. Possibly as early as 771, her remains were translated to the newly built church of Sainte-Marie-Madeleine in Vézelay in Burgundy, whereas towards the end of the fourteenth century, veneration for the Magdalene received a new impetus in the south of France, in Saint-Maximin-la-Sainte-Beaume.

On the basis of legends like Voragine's, Mary Magdalene has sometimes been described as a courtesan or even an outright prostitute. These qualifications are a result of the hypothetical identification of the Magdalene with the sinner Luke mentions in the house of the Pharisee. The Church Father Gregory, in the sermon just quoted, after having said that, to him, the Magdalene was identical with the Mary possessed by seven devils, continues: 'And what did these seven devils signify, if not all the vices? [...] It is clear, brothers, that the woman previously used the unguent to perfume her flesh in forbidden acts. ${ }^{5}$

3 Fragments of the Gospel of Mary were discovered in 1896; The Gospel of Philip, along with some other important Early Christian writings, in 1945.

4 Jacobus de Voragine (1993), pp. 374-384.

5 Homilia xxxiii: Gregory the Great (1999), p. 288-298, English quotation after Haskins (1993), p. 96. 
The emphasis the Roman Catholic Church traditionally put on Mary's sinful origins, as well as her penance and virtuous later life contrasting with them, have been reason to present her as exemplary of the salutary effects of repentance. She became a patron saint to converts of all kinds, and especially 'fallen women' and prostitutes, and the centres founded to their relief. It was only in the twentieth century that the Church implicitly dissociated itself from these views. In the 1969 edition of the Roman Missal the knot of the figures of the Magdalene, Mary of Bethany and the anonymous sinner respectively, was finally disentangled. In the Orthodox tradition, however, this distinction has always remained doctrinal: the Eastern Church has never considered Mary Magdalene other than as an example of virtue, even before her conversion. ${ }^{6}$ Also in many Protestant Churches as well as in the Church of England, the Magdalene was not in the first place regarded as a sinner, but rather as an exemplary disciple of Jesus, and sometimes even as his apostle. The fact that two prestigious English academic colleges, in Oxford and Cambridge respectively, have been dedicated to the saint, undoubtedly has to do with this English variant of the veneration for the Magdalene.

It can hardly come as a surprise that works of visual art in Western Europe reflect the image of Mary Magdalene as it arises from the written sources. ${ }^{7}$ Time and again, the saint has been portrayed in paintings and sculptures, drawings, and prints: now as the young and elegant, but sinful lady she once was, now as a convert, and now as the haggard ascetic she became towards the end of her life. In general, she can easily be recognized by her long, often reddish hair, which had played such an important part in the episode in the Pharisee's house. Almost always she is holding an ointment jar of some sort, in reference to the anointment of Christ's feet, as well as to her efforts to anoint the latter's body after the crucifixion. Clearly, the confusion over the Magdalene's identity persists in visual form. Indeed, in the arts, yet another case of mistaken identity was added to the others. In depictions of the Magdalene as an anchorite in the wilderness, her appearance often seems to be borrowed from that of an Early Christian hermit saint going by the name of Maria Aegyptiaca. This fourth- or fifth-century 'Mary of Egypt' was known to have followed an insatiable carnal lust for seventeen years before she repented, upon looking at an icon of the Holy Virgin in Jerusalem. After this she decided to give up her vile ways and to withdraw in the desert to live an ascetic life in solitude. The

6 According to this tradition, she would have travelled not to France, but to Ephesus and died there.

7 For general studies on the iconography of Mary Magdalene and her legend, see e.g. Kirschbaum (1968-1976) vol. 7, 516-541, Ingenhoff-Dannhäuser (1984), Rafanelli (2004). 
parallels with the Magdalene's conversion and subsequent conduct are evident, as is, in images of the saint, the emphasis on her long hair. Whereas, for instance, the Golden Legend has it that Mary of Egypt lived in the desert, 'naked, the body blackened and burned by the fiery sun,', in iconography she is always depicted covering her nudity with her own long hair. Since the thirteenth century and especially in Italy, the image of an emaciated, naked woman covering herself with her long hair has often been used in depictions of the Magdalene as well.

Narrative scenes taken from the Magdalene's legend have, since the early Middle Ages, also been highly popular. Innumerable are the depictions of, among others, Mary Magdalene in the house of the Pharisee. Other examples include the episode of her presence at Christ's crucifixion and the subsequent lamentation over his dead body, as well as the story of her encounter on Easter morning with the risen Christ, commonly known as Noli me tangere.

Yet mirroring most hagiographical literature, the theme of Mary's conversion - however crucially important it is for the understanding of her progress - is rarely narrated in the visual arts. Sometimes it is hinted at in an allegorical way. In these cases, the saint is usually shown in splendid attire, but also shedding tears or close to doing so. She lets down her hair and symbolically disposes of her riches by putting aside her jewellery. Instances of this iconographical formula, which developed in full only during the Counter Reformation climate of the late sixteenth and seventeenth centuries, include famous works by Caravaggio (Rome, Galleria Doria Pamphilij, ca. 1596, Figure 9.1), and Charles le Brun (Paris, Musée du Louvre, 1655). Those few scenes which do narrate the conversion are found somewhat earlier, both in Northern Europe and Italy and, judging from the few examples that have come down to us, only within the relatively limited time-span of three quarters of a century from approximately 1490 to 1565 .

\section{The Magdalene's Conversion in Sacred Drama}

Images depicting a narrative scene of Mary Magdalene's conversion seem to have been based primarily on one particular set of sources. For, as we shall see, they almost exclusively show some variant of a story which tells of the sinful Mary listening to Christ delivering a sermon, which in turn induced her to

8 Jacobus de Voragine (1993), pp. 227-229. 


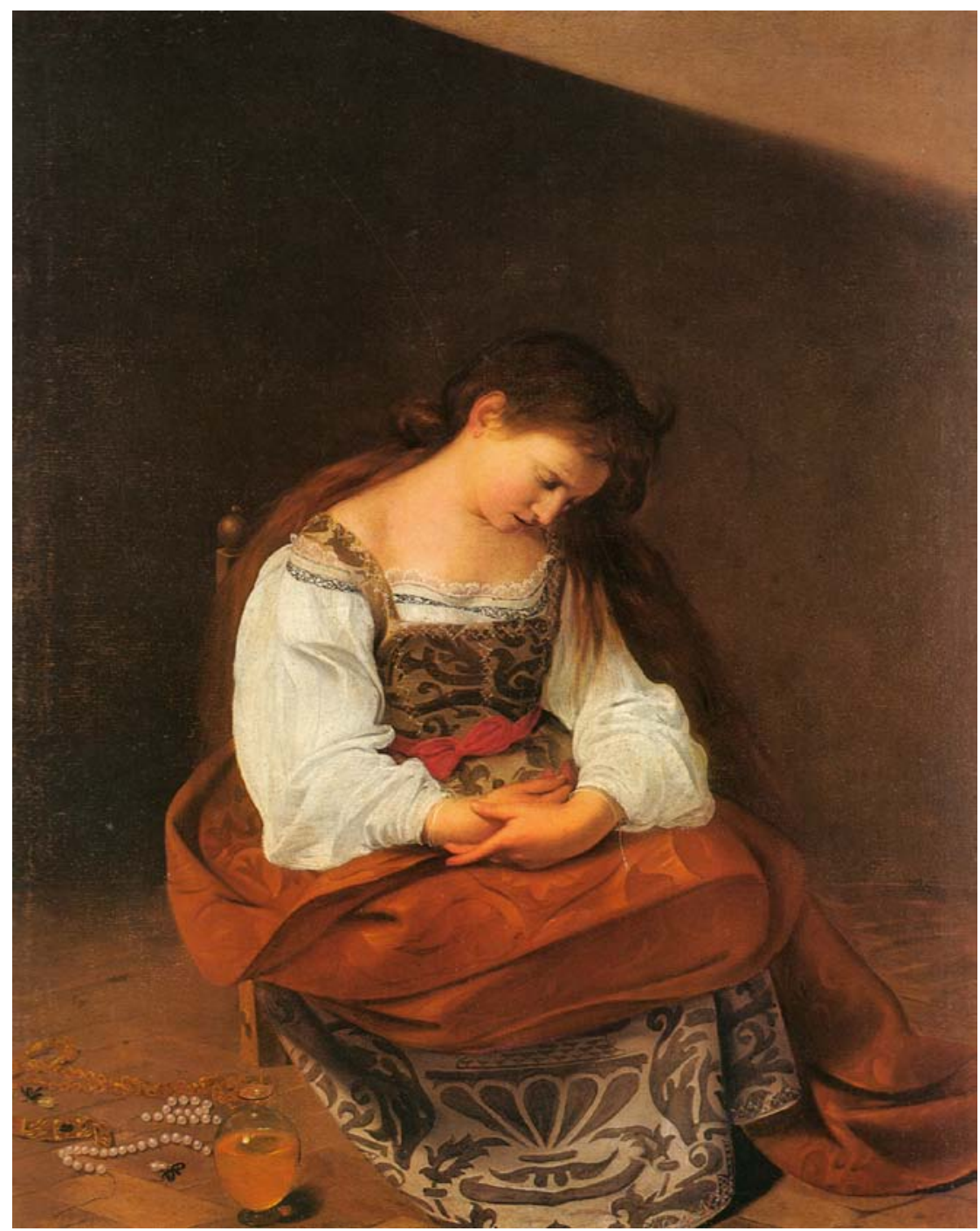

FIgUre 9.1 Caravaggio, The penitent Mary Magdalene, canvas, c. 1596, Rome, Galleria Doria Pamphilij. Centrum voor Kunsthistorische Documentatie, RADBOUD UNIVERSITY NIJMEGEN.

repent. This story has been repeated many times in accounts from Late Mediaeval and Early Modern sacred drama. ${ }^{9}$

9 A notable exception is an account of the story in Pietro Aretino's tract La humanità di Christo, first published in 1535. This text may have been the source for the depiction of the theme in a painting of ca. 1548 (now in London, National Gallery), by the Venetian painter 
Being one of the protagonists in the events surrounding Christ's death and resurrection, the Magdalene plays a major role in Easter plays from as early as the twelfth century onwards. ${ }^{10}$ In addition in later versions of these, the story of Mary's conversion is sometimes recounted at length and in detail. Generally the setting is Bethany, and it is assumed that the biblical Mary who is living in that town is identical to the Magdalene. Her sister, Martha, and sometimes also the latter's servant, Marcella, take pains to persuade Mary to go and attend the sermon Christ is about to deliver. Though reluctant at first, the Magdalene in the end gives in, in keeping (it seems) with her supposed predilection for material wealth and physical beauty, since she is attracted to the idea of making the acquaintance of the eloquent and fine-looking newcomer.

Plays recounting the episode of Mary's conversion appear to have come into being in midfourteenth-century Germany, with scores of versions and variants following thereafter all over Europe. ${ }^{11}$ Without a doubt only part of this number have survived in manuscript or print. Of the texts which have come down to us, a well-known example is the French Mystère de la passion, written by Jean Michel in the second half of the fifteenth century. ${ }^{12}$ This play tells of the Magdalene who, having just heard that Jesus is the 'most handsome man in the world' and apparently desiring to seduce him, makes her way to the temple to see and hear him preach. Miraculously, she converts on the spot and from that time on she is a follower of Christ. In Italy, quite a number of sacred dramas (rappresentazioni in Italian) were published during the sixteenth century. For instance, a text entitled Rappresentatione di un miracolo di Santa Maria Maddalena was first published in Florence in 1516 and saw several editions during the latter half of the sixteenth century. ${ }^{13}$ A second Italian play, explicitly entitled Rappresentazione della conversione di Santa Maria Maddalena ('Sacred drama of the conversion of Saint Mary Magdalene') was first published in Florence in $1554 \cdot{ }^{14}$

As an example of the phrasing (in rhyming verse) and tone of such texts, we should consider a few lines from the Rappresentazione di un miracolo of 1516 . Trying to talk her sister into going to the temple the next morning to hear Christ speak, Martha says:

\footnotetext{
Paolo Veronese: see Rosand (2011), and seems to have been important for seventeenthcentury Italian painting as well: Bull (2011).

$10 \quad$ Malvern (1975) 100.

11 Kirschbaum's Lexikon mentions a Frankfurt play of 1350: Kirschbaum (1968-1976) 7, col. 533. 
Di mio parlar tanto dilett arai, quanto drento al tuo cor sentisse mai. Io so che ti diletta e dà piacere vedere un giovan di gentil aspetto. E quanto io posso intendere e sapere da molti esser veduta hai gran diletto; io ti vo' far, sorella mia, vedere un uom che mai vedesti el più perfetto; di tal bellezza è tanto decorato che proprio pare un angelo incarnato.

(From my talking you will have as much delight as you have never felt in your heart. I know that you take delight and pleasure in seeing a young man with a nice appearance. And, as far as I understand and know, you take great delight in being seen by many. My sister, I will show you a man as perfect as you will never have seen; gifted with such beauty that he really seems an angel incarnate.)

Martha goes on extolling Christ's physical beauty and eloquence, and indeed succeeds in persuading Mary. But leaving her sister alone after the dialogue, as if to make explicit not only the essential impropriety of Mary's initial intention, but also to justify her own argument, Martha mumbles to herself:

Benché suo desiderio non sia buono, ma lascivo e carnal secondo il senso, per questa volta al tutto certa sono, che non farà peccato, se ben penso: mutato il cor, ricevrà perdono per grazia del Signor, che è bene immenso. Quel che 'l dolce maestro m'ha promesso, senza alcun dubio mi sarà concesso.

(Although her desire is not right but lascivious and carnal, directed only by the senses, I, this time, am entirely certain that it will not do any harm if I think: 
once she has changed her heart, she will be forgiven by the grace of the Lord, whose mercy is immense. That which the sweet master has promised will without any doubt be granted to me.)

In fact, on the next day Mary accompanies Martha to the place where Christ will deliver his sermon. He starts speaking about sin and penance, after which the moment of Mary's conversion is described in the following stage direction:

Voltasi CHRISTO verso Maria Maddalena, e segue, e mentre che dice con efficacia, Maddalena comincia a piangere, e inclina il capo in grembo, e cuopresi con uno sciugatorio della ancilla sua.

(Christ turns to Mary Magdalene and follows her, and while he speaks in well-chosen terms, the Magdalene starts to cry and lowers her head to her lap, and covers herself with her servant's towel. $)^{15}$

\section{The Magdalene's Conversion Depicted}

According to the texts of these popular stage plays, the event of Mary's conversion occurred when she heard Christ delivering a sermon, sometimes specified as a homily on penance. As we have also seen, there were many different versions of the story, probably even much more than the ones that have come down to us, in texts that have gone astray, or perhaps also in plays for which no record exists. A few depictions of the story in paintings show a similar variety.

One interesting instance is a scene that once belonged to an early-sixteenthcentury tripartite altarpiece. The anonymous author of the work must have been active in the Flemish city of Antwerp. In art historical literature he has become known as the 'Master of the Magdalene Legend'. ${ }^{16}$ The triptych, to be dated in around 1518 , has been dismembered and partly cut up into fragments that have wound up in various collections. A reconstruction of it shows a series of scenes focused on the Magdalene's life and legend. The central panel has the

15 All quotations from D'Ancona (1872) 1, 391-425, the story of Mary's conversion on pp. 395-399.

16 Tombu (1927), Friedländer (1975) 13-14, 91, pl. 7, Cohen (2001) 37-38, and, for a discussion of a few other instances, in early sixteenth-century Netherlandsh painting and manuscript illumination, of Mary on horseback: 132-134. For a recent discussion of the Master and the triptych in question, see: Bücken and Steyaert (2013) 342-345. 


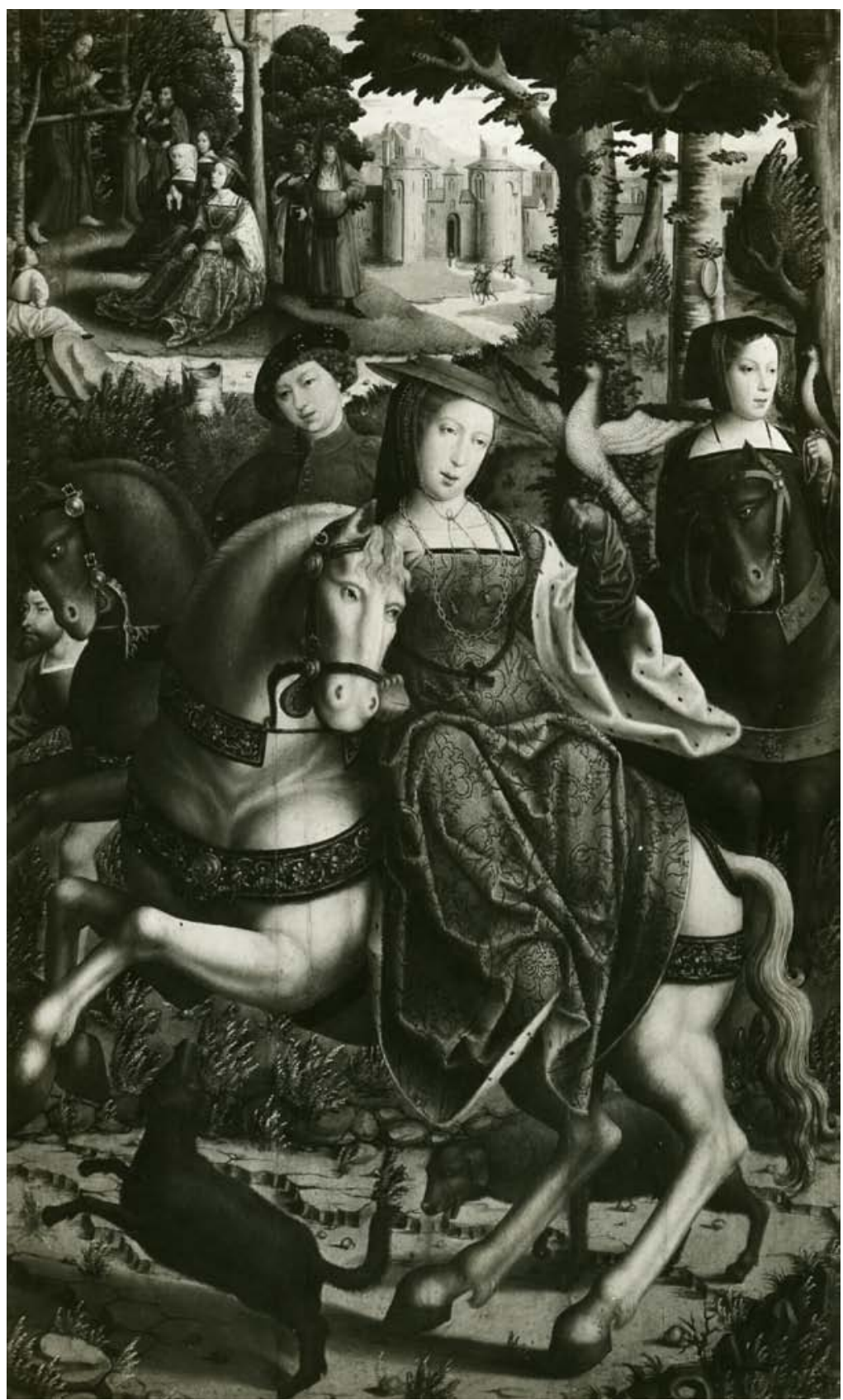

FIGURE 9.2 Master of the Magdalene Legend, The worldly Mary Magdalene, panel, c. 1518, Gemäldegalerie Staatliche Museen Zu Berlin, Stiftung Preußischer Kulturbesitz, Lost in Flakbunker Berlin-Fiedrichshain, May 1945 (рното: GUSTAV SCHWARZ). 
episode in the house of the Pharisee, as well as the scene of Christ raising Lazarus from the dead. The side panel on the right shows an unusual depiction of Mary Magdalene preaching, probably to converts in the south of France. The panel to the left is known only by way of a photograph, as it has been destroyed in Berlin during the Second World War (Figure 9.2). The best part of this panel depicts Mary Magdalene in her former, aristocratic appearance, riding a horse side-saddle, and apparently engaged in a hunting party. A much smaller scene in the background shows Christ standing on an improvised platform made out of branches, which echoes the one on which the Magdalene herself is standing in the image on the other side panel. Christ is addressing a group of people among whom the Magdalene can be recognized.

In Italian art we know of an even earlier depiction of the theme. Some twenty-five years before the 'Magdalene Master' was to paint his triptych, the great Florentine Renaissance master, Sandro Botticelli, had painted the episode on a small panel (now in Philadelphia, John G. Johnson Collection, Figure 9.3). It shows Christ standing on some kind of rise in a loggia, while he addresses a group of people standing and kneeling before him. Apparently, the isolated, haloed figure dressed in red to the far left should be identified as the Magdalene. Originally, the small panel was part of a predella (i.e. a low, rectangular and often decorated part at the bottom of an altarpiece), with various narrative scenes from the Magdalene's legend. The altarpiece's main panel (now in London, Courtauld Gallery) has a depiction of the Holy Trinity flanked by two penitent saints par excellence, John the Baptist (with his camel-hair shirt) and Mary Magdalene (her nudity, Maria Aegyptiaca-style, covered by her own long hair only). Botticelli made the work in the years 1491-1493, for the church of the Florentine confraternity of Convertite which, appropriately in this context, was a community made up of former prostitutes. ${ }^{17}$

Almost to underline the scarcity of examples of the short-lived tradition of depictions of the theme, only a few more instances can be mentioned, all by sixteenth-century artists. One is a panel painted in around 1562 by the Brussels-born artist Peter de Kempeneer who, having worked for some 25 years in Spain and Italy, became known as Pedro Campaña (the work is now being kept in London, National Gallery, Figure 9.4). ${ }^{18}$ In the interior of a temple-like building, Christ sits on a platform under a baldachin. A large number of men surround him, while he is pointing with his right hand in the direction of a second group, made up largely of women, to the right of the composition. Among these, the kneeling figure of Mary Magdalene is not hard to recognize. She is

$17 \quad$ Lightbown (1989) 202-207, pl. 75-79.

18 Penny (2008) 68-77. 


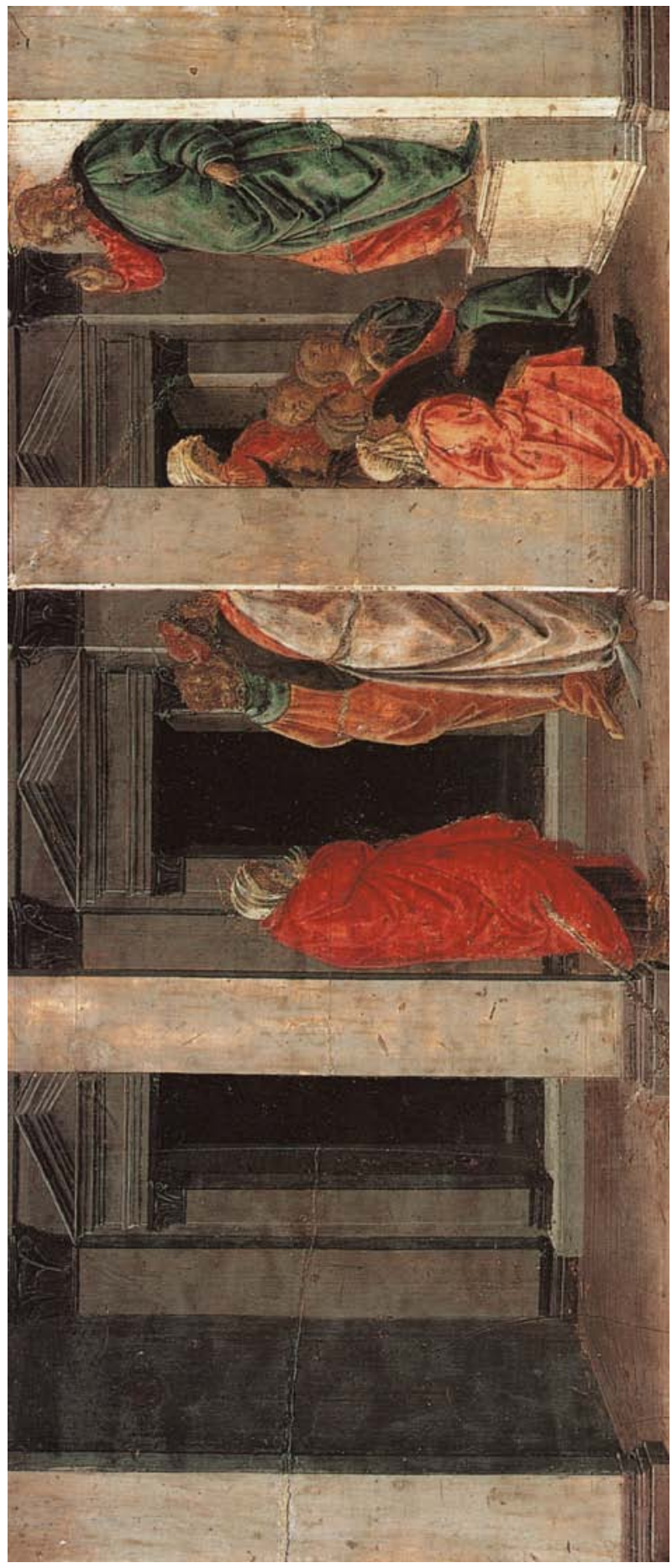

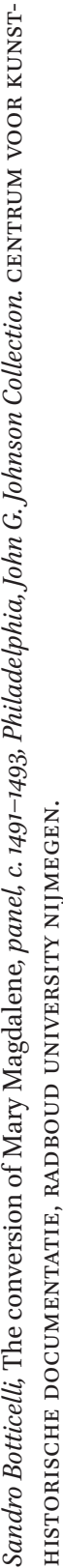

n. 


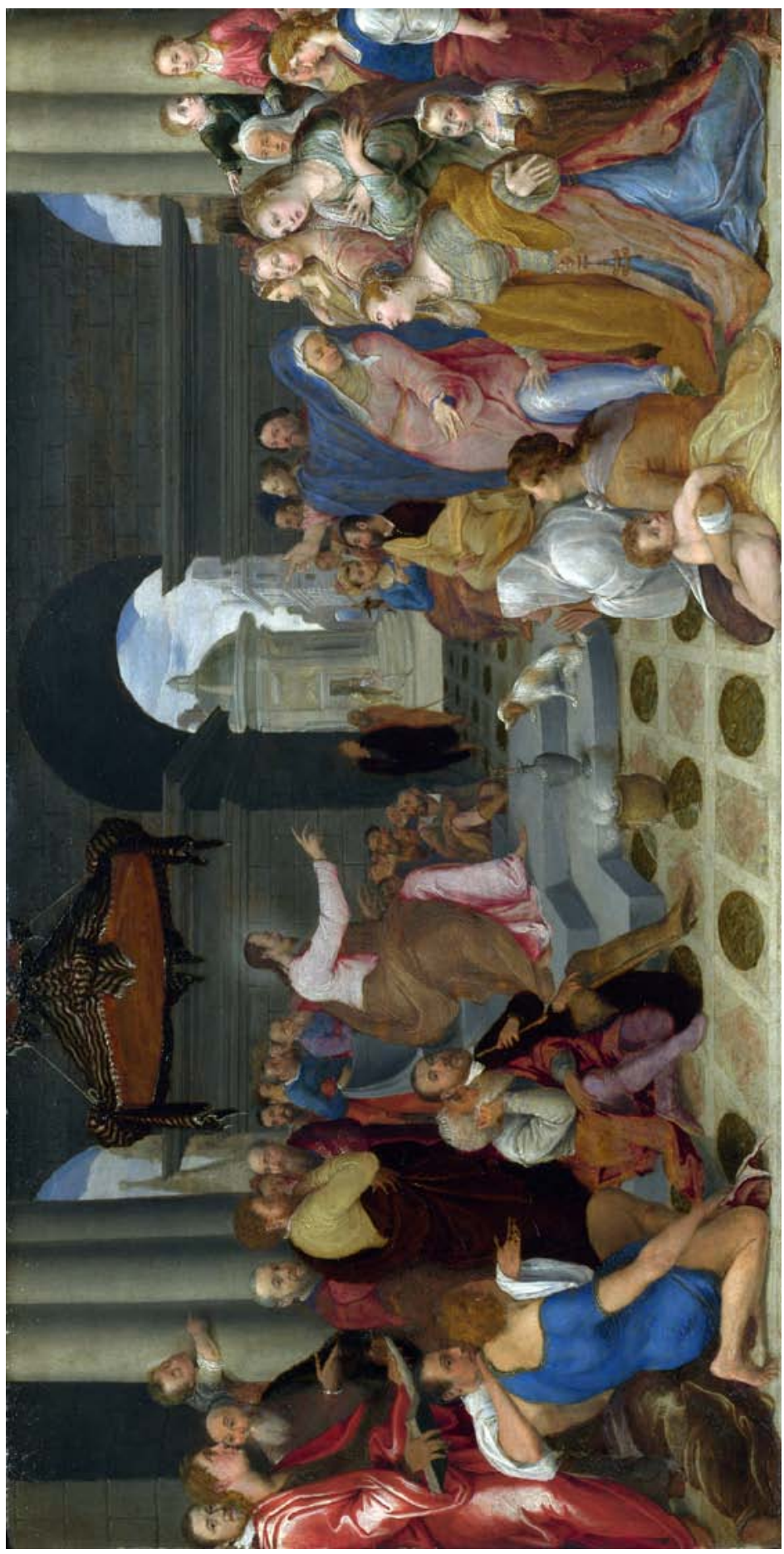

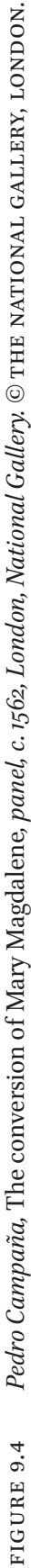




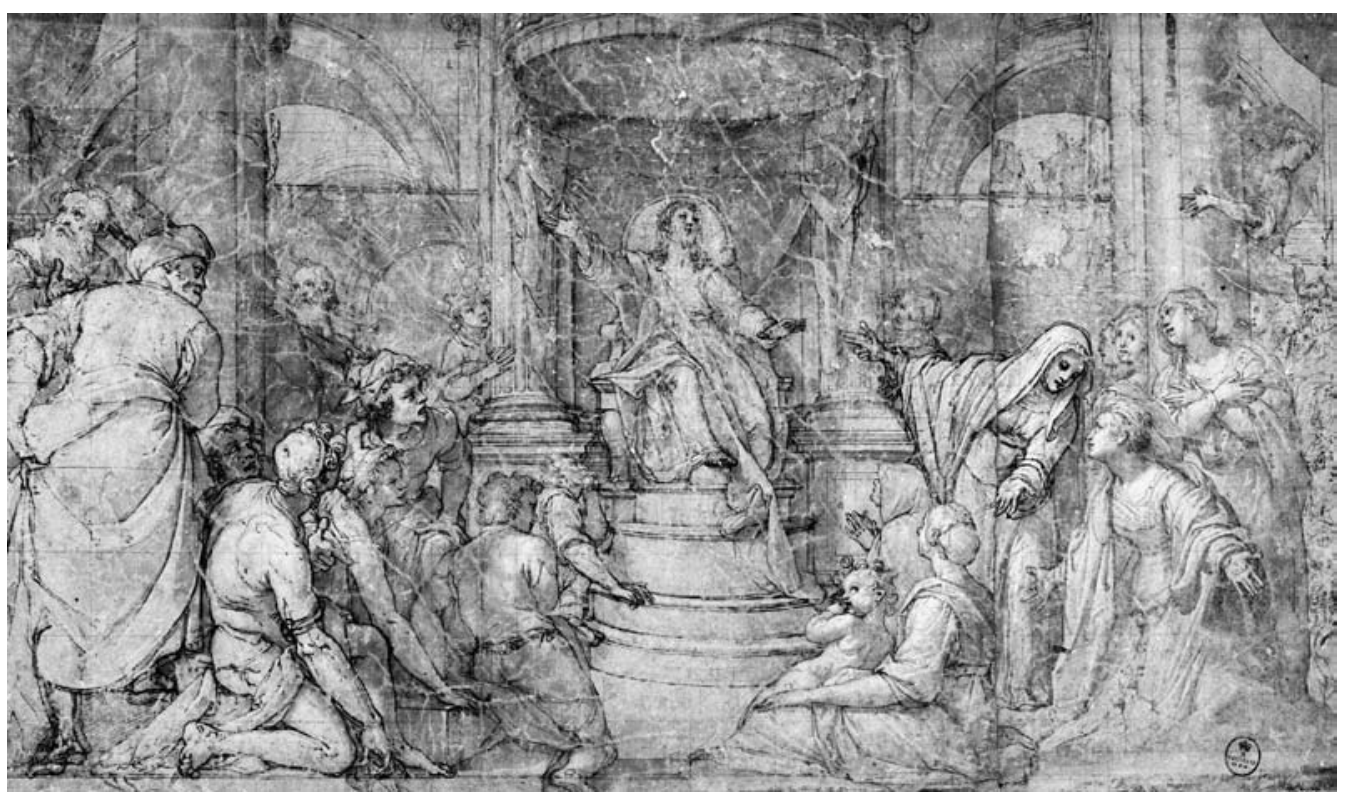

FIGURE 9.5 Federico Zuccari, The conversion of Mary Magdalene, drawing, c.1560, Florence,

Galleria degli Uffizi. ARCHIVIO FOTOGRAFICO, POLO MUSEALE FIORENTINO.

being accompanied by a woman - doubtlessly her sister Martha - who is addressing her and at the same time gesturing towards Christ. Pedro Campaña must have based his composition (at least in part) on a fresco the Florentine painter Federico Zuccari had made in the early 1560 s in a chapel in the church of San Francesco della Vigna in Venice (Figure 9.5). The mural itself has been destroyed shortly after its completion, but something of its composition can be gathered by way of a preparatory drawing attributed to the artist himself. ${ }^{19}$ Especially the part on the right, with the figures of the Magdalene and Martha, resembles Campaña's composition to a great extent.

One last sixteenth-century painting depicting the episode of Mary's conversion is a fresco by the Piedmontese painter Gaudenzio Ferrari. In the years around 1530, he executed an impressive and complex decoration in the choir and two side chapels of the church of San Cristoforo in Vercelli, a town situated about halfway between Milan and Turin. ${ }^{20}$ In one of these chapels, Gaudenzio painted a fresco of the Assumption of the Virgin over the altar, as well as four

19 Zuccaro took over from Battista Franco after the latter had died in 1561 . He painted two laterali in the chapel, one the Conversion of the Magdalene, the other a Raising of Lazarus. See Rearick (1959) 129-135.

20 For the decoration in San Cristoforo, see: Bo (2001), Villata (2003) 61-84. 


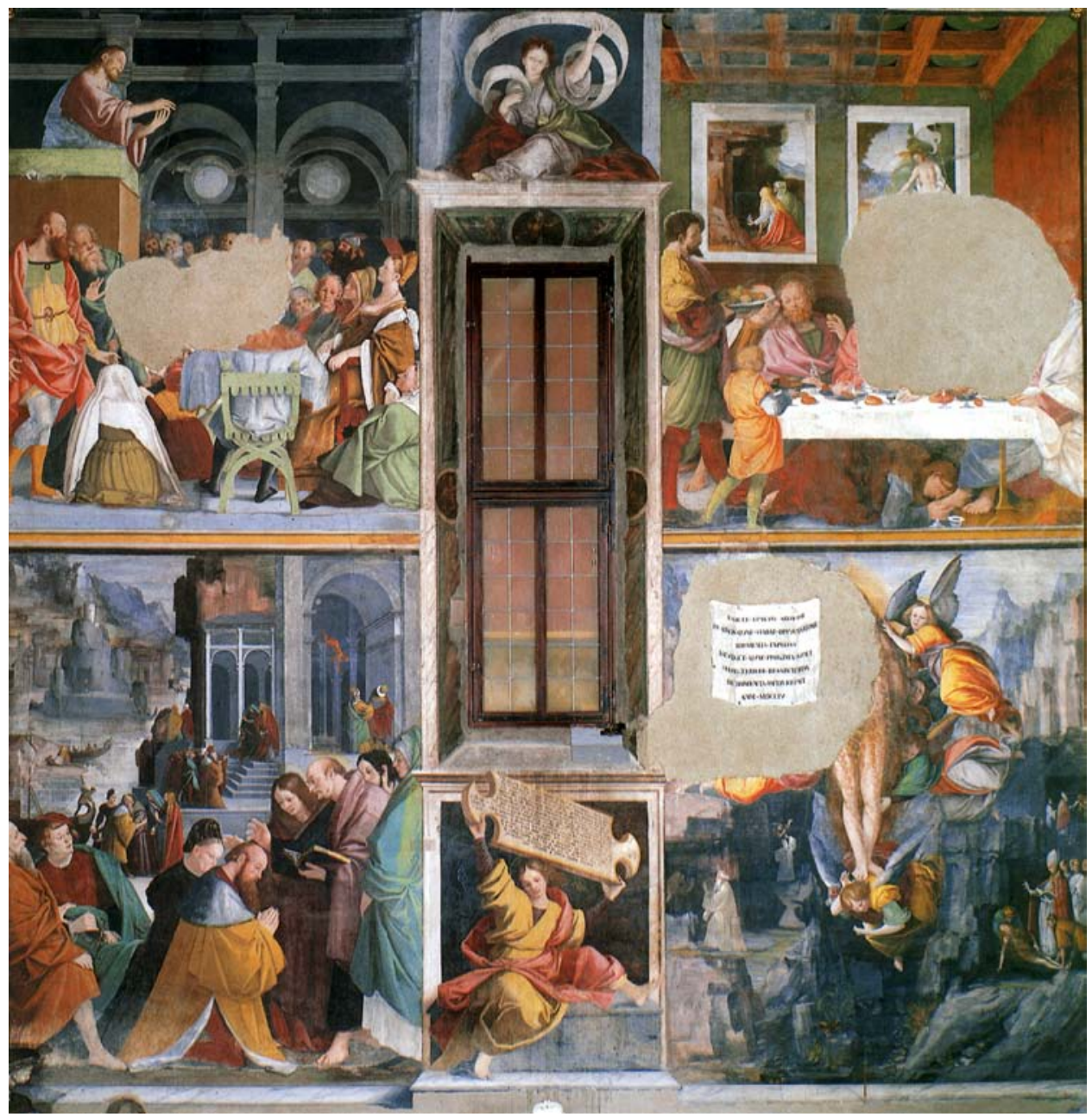

FIgURE 9.6 Gaudenzio Ferarri, Scenes from the life of Mary Magdalene, fresco, 1532, Vercelli, San Cristoforo. CENTRUM Voor KUNSTHISTORISCHE DOCUMENTATIE, RADBOUD UNIVERSITY NIJMEGEN.

scenes drawn from the life of Mary Magdalene on the wall to the right (Figure 9.6). ${ }^{21}$ These four frescoes are arranged into two superimposed registers. The first, placed in the upper left corner, depicts the episode of Mary Magdalene's conversion (Figure 9.7). The other three are: Christ in the house of the Phari-

$21 \quad$ For Gaudenzio Ferrari, see e.g.: Sacchi (1996) 573-581 (with ample references to earlier literature). The results of my more comprehensive research into Gaudenzio Ferrari and his decorations in San Cristoforo, will be presented elsewhere, with full bibliography. 


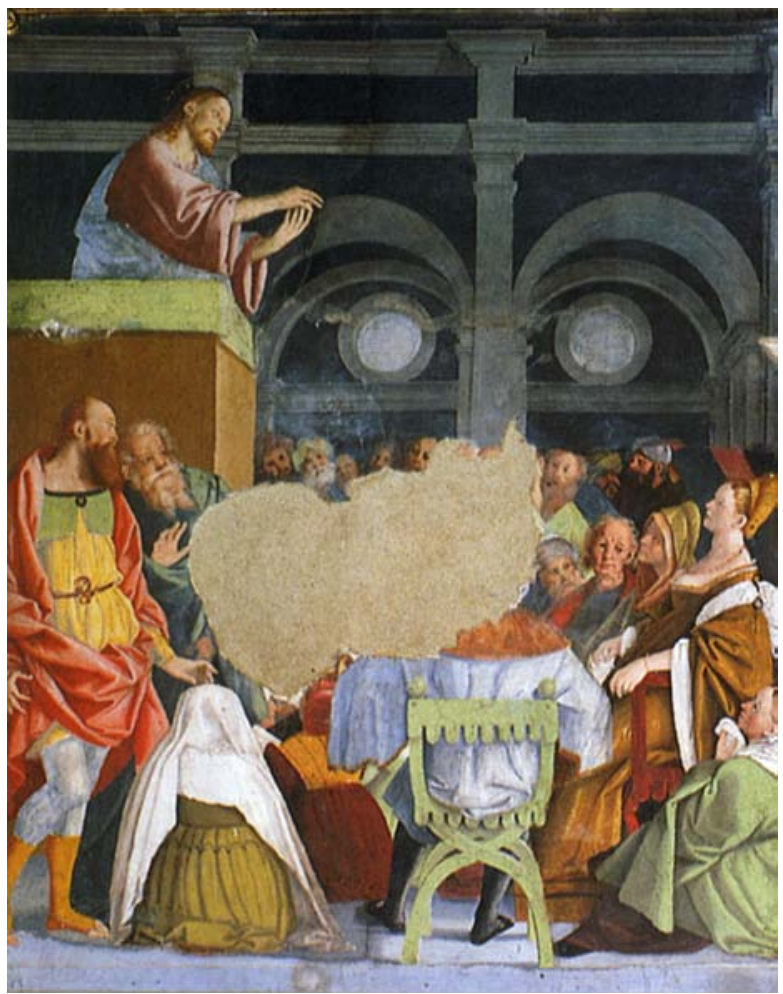

FIGURE 9.7 Gaudenzio Ferarri, Scenes from the life of Mary Magdalene (detail: Mary Magdalene's conversion), fresco, 1532, Vercelli, San Cristoforo. CENTRUM VOoR KUNSTHISTORISCHE DOCUMENTATIE, RADBOUD UNIVERSITY NIJMEGEN.

see, the Baptism of the prefect of Marseille, and the Magdalene in the desert elevated by angels, respectively. The conversion fresco was badly damaged in the early eighteenth century, when a considerable portion of the painted surface disappeared. However, it can clearly be made out that Gaudenzio's rendering of the episode shows an interior with Christ standing high up on a pulpit, preaching and counting his arguments on the fingers of his right hand. The room is filled with a public of figures standing, or sitting either on chairs or simply on the floor. The richly dressed lady sitting in a comfortable seat at the far right, apparently listening attentively but as yet not showing any sign of penance or remorse, should be identified as the Magdalene.

Gaudenzio Ferrari's fresco, despite the damage it has suffered, is especially interesting, because in art historical literature it has hitherto neither been studied in the context of the iconography of the Magdalene's conversion, nor 
ever been related to any written source. If we were to try and single out a particular version of the play as a direct source for the design and composition of Gaudenzio Ferarri's fresco of Mary's conversion, rather than the text quoted above, the already mentioned Rappresentazione della conversione of some forty years later would perhaps present itself as a suitable candidate. At least some details in Gaudenzio's fresco appear to reflect the wording of the event in this particular play. For instance, the relevant stage direction reads: Iesù entra nel tempio, e salito sul pergamo, e' comincia a predicare ('Christ enters the temple, and after having climbed the pulpit he begins to deliver his sermon'). The explicit mention of a pulpit that one must climb seems to be a distinguishing element of this particular text, and the same holds true for the stage direction of how Mary's donzelle parano una sedia dinanzi al pergamo, e lei tutto pomposo vi si posa su ('Mary's serving girls adorn a chair in front of the pulpit, on which the Magdalene pompously takes her place'). Both elements can be seen overtly in the fresco.

This is not to suggest, however, that the painter or his patrons were aware of this particular text. For whilst the play in question seems to have been performed during the fifteenth century, ${ }^{22}$ it was not published for the first time until eighteen years after the mural's completion. Moreover, like many other sacre rappresantazioni, it probably originated in Florence, or elsewhere in Tuscany, locations at a considerable distance from the Northern Italian town of Vercelli. Finally, there must have been many other comparable texts that in the course of time vanished without a trace. Rather, the quotes from the Rappresentazione della conversione show that, in one way or another, these particular narrative elements were known in Piedmont in around 1530: in the depiction by Gaudenzio Ferrari, and most probably also in pieces of sacred drama.

\section{Conclusion}

The handful of images narrating Mary Magdalene's conversion, all dating from the late fifteenth or sixteenth centuries and originating in both the Netherlands and Italy, are characterized by a variety of media and dimensions, as well as interpretations of the scene. Botticelli presented it on a small panel, and in a rather summary way. In a plain setting, Christ stands upon a soapbox while the Magdalene watches him from the corner of the room. The lost side panel of the triptych painted by the Master of the Magdalene Legend shows an equally

\footnotetext{
22 Although he does not give any information about the date of the play, Luigi Banfi implicitly placed it in the fifteenth century by including it in his Teatro del Quattrocento (1997).
} 
small scene, this time taking place outdoors and with Christ on a simple rostrum of branches whilst Mary is seated on the floor amidst other listeners. Federico Zuccari's preparatory drawing for a monumental fresco, and Pedro Campaña's panel inspired by it, offer more elements that allude to the written sources. Christ is sitting on a chair whilst Mary is kneeling before him, and they are surrounded by a host of bystanders in the interior of a temple. Gaudenzio Ferrari's fresco provides something more tangible through the inclusion of the scene in a chronological series of depictions of episodes from Mary's life, and by presenting Christ on a pulpit with the Magdalene on a chair before him elements which recur in (later) written Italian rappresentazioni. Most probably, the other artistic renderings ultimately derive from the descriptions of the scene in sacred drama, but the theme never seems to have been subject to any standard iconography.

The conversion theme is an example par excellence of the sometimes complex relationship between texts and images in the late Middle Ages and the Renaissance. Depictions of the theme turn out to be translations into visual form of biblical texts, hagiographies and theological commentaries, and, finally, written accounts of sacred drama.

\section{References}

Banfi, L. 1997. Teatro del Quattrocento, sacre rappresentazioni. Turin (first published in 1963 as Sacre rappresentazioni del Quattrocento).

Bo, P. 2001. Gaudenzio Ferrari a San Cristoforo in Vercelli, Vercelli.

Bull, D. 2011. Caravaggio and Pietro Aretino. In The Burlington Magazine, 153, 607.

Bücker V. and G. Steyaert. 2013. De erfenis van Rogiervan der Weyden; de schilderkunst in Brussel 1420-1520, Tielt.

Cohen, B.M., 2001. Saint Mary Magdalen as a Cultural Symbol in the Low Countries, c. 1450-1530 (diss. State University of New York). New York.

D’Ancona, A. 1872. Sacre rappresentazioni dei secoli XIV, XV, e XVI (vol 1-3). Florence.

Friedländer, M.J. 1967-1975. Early Netherlandish Painting (vol. 1-14), Brussels, The Hague

Gregory the Great. 1999. Gregorius Magnus Homiliae in Evangelia, Turnhout(Instrumenta lexicologica latina. Series A, 120).

Haskins, S. 1993, Mary Magdalene, Myth and Metaphor. London.

Ingenhoff-Dannhäuser, M. 1984. Maria Magdalena: Heilige und Sünderin in der italienischen Renaissance: Studien zur Ikonographie der Heiligen von Leonardo bis Tizian. Tübingen.

Jacobus de Voragine. 1993. The Golden Legend: Readings on the Saints (transl. William Granger Ryan), Princeton. 
Jansen, K.L. 1999. The Making of the Magdalen; Preaching and Popular Devotion in the Later Middle Ages. Princeton.

Jodogne, O. ed. 1959. Jean Michel, Le Mystère de la Passion, 1486. Gemblond.

Kirschbaum, E (ed). 1968-1976. Lexikon der christlichen Ikonographie (vol. 1-8). Rome etc. (repr. Rome 1990).

Lightbown, R. 1989. Sandro Botticelli, Life and Work. New York.

Malvern, M.M. 1975. Venus in Sackcloth; the Magdalen's Origins and Methaphoses. London, Amsterdam.

Penny, N. 2008. National Gallery Catalogues; the Sixteenth Century Italian Paintings, Vol. II, Venice 1540-160o. London.

Rafanelli, L.M. 2004. The Ambiguity of Touch: Saint Mary Magdalen and the Noli me Tangere Theme in Early Modern Italy (diss. New York University). New York.

Rearick, W.R. 1959, Battista Franco and the Grimani Chapel. In Saggi e memorie di storia dell'arte 2, 107-139.

Ricci, C. and M. Marin ed. 2006. L'apostola Maria Maddalena, inascoltata verità. Bari.

Rosand, D. 2011. Veronese's Magdalene and Pietro Aretino. In The Burlington Magazine, 153, 392-394.

Sacchi, R. 1996, Ferrari, Gaudenzio. In Dizionario biografico degli italiani, 46, 573-581. Rome

Tombu, J. 1927. Un triptyque du maitre de la légende Marie-Madeleine. In Gazette des Beaux-Arts, 15, 299-311.

Villata, E. 2003. Gaudenzio Ferrari ed Eusebio Ferrari. In Artifigurative a Biella e a Vercelli; il Cinquecento, ed. V. Natale, 61-84. Biella. 